Article

\title{
Biological and Enzymatic Characterization of Proteases from Crude Venom of the Ant Odontomachus bauri
}

\author{
Mariana Ferreira Silva ${ }^{1}$, Caroline Martins Mota ${ }^{1}$, Vanessa dos Santos Miranda ${ }^{1}$, \\ Amanda de Oliveira Cunha ${ }^{1}$, Maraísa Cristina Silva ${ }^{1}$, Karinne Spirandelli Carvalho Naves ${ }^{2}$, \\ Fábio de Oliveira ${ }^{3,4}$, Deise Aparecida de Oliveira Silva ${ }^{1}$, Tiago Wilson Patriarca Mineo ${ }^{1}$ and \\ Fernanda Maria Santiago ${ }^{1, *}$
}

Received: 14 August 2015; Accepted: 9 October 2015; Published: 30 November 2015

Academic Editor: Glenn F. King

1 Institute of Biomedical Sciences, Laboratory of Immunoparasitology "Dr. Mario Endsfeldz Camargo", Federal University of Uberlândia, Av. Pará 1720, Uberlândia 38400-902, Brazil; marianaa_fs@hotmail.com (M.F.S.); carolinemartinsm@yahoo.com.br (C.M.M.); vanessa.smiranda@hotmail.com (V.S.M.); amanda.olicunha@hotmail.com (A.O.C.); maraisa2003@yahoo.com.br (M.C.S.); daosilva@yahoo.com.br (D.A.O.S.); tiagomineo@icbim.ufu.br (T.W.P.M.)

2 Institute of Biomedical Sciences, Laboratory of Clinical Bacteriology, Federal University of Uberlândia, Av. Pará 1720, Uberlândia 38400-902, Brazil; kscnaves@icbim.ufu.br

3 Institute of Biomedical Sciences, Laboratory of Biophysics, Federal University of Uberlândia, Av. Pará 1720, Uberlândia 38400-902, Brazil; foliveira@umuarama.ufu.br

4 National Institute in Science and Technology in Nanobiopharmaceutics (NanoBiofar), Belo Horizonte-MG 31270-901, Brazil

* Correspondence: fmsantiago@icbim.ufu.br; Tel.: +55-34-3225-8666; Fax: +55-34-3218-2333

\begin{abstract}
Hymenoptera venoms constitute an interesting source of natural toxins that may lead to the development of novel therapeutic agents. The present study investigated the enzymatic and biological characteristics of the crude venom of the ant Odontomachus bauri. Its crude venom presents several protein bands, with higher staining for six proteins with gelatinolytic activity $(17,20,26,29,43$ and $48 \mathrm{kDa})$. The crude venom showed high proteolytic activity on azocasein at optimal pH 8.0 and $37^{\circ} \mathrm{C}$. In the presence of protease inhibitors as aprotinin, leupeptin and EDTA, the azocaseinolytic activity was reduced by $45 \%, 29 \%$ and $9 \%$, respectively, suggesting that the enzymes present in the crude venom belong to the three classes of proteases, with the serine proteases in greater intensity. The crude venom degraded the fibrinogen $\alpha$-chain faster than the $\beta$-chain, while the fibrinogen $\gamma$-chain remained unchanged. In biological assays, O. bauri venom showed hemolytic and coagulant activity in vitro, and defibrinating activity in vivo. In addition, the venom showed antimicrobial activity against Staphylococcus aureus and Escherichia coli as well as antiparasitic activity on Toxoplasma gondii infection in vitro. In that sense, this study sheds perspectives for pharmacological applications of O. bauri venom enzymes.
\end{abstract}

Keywords: Odontomachus bauri; crude venom; proteases; Toxoplasma gondii

\section{Introduction}

Ants of the genus Odontomachus are widely distributed in tropical and warm countries, being especially abundant in the neotropics [1,2]. Ants of the species $O$. bauri usually build their nests in the ground, protecting them from direct sunlight and choosing the place to build them far from environmental disturbance. When nests are disturbed, these ants attack their aggressors and their bites cause immediate acute pain and a burning sensation [3]. 
Also known as trap jaw ants, their movements are extremely fast and produce remarkably predatory attacks $[4,5]$. During predatory strikes, $O$. bauri mandibles close at a speed ranging from 35 to $64 \mathrm{~m} / \mathrm{s}$, far surpassing the speeds of other ballistic predatory appendages already documented in the animal kingdom [5], including the discharge of the cnidarian nematocyst [6].

In addition, these ants have the ability to disable prey because their mandibles were evolutionarily adapted for locomotion. O. bauri specimens use their claws to perform some jumps, which have the assumed forms of "bouncer defense" [7].

The venom of $O$. bauri and other insects of the order Hymenoptera, is produced in venom glands (structure located in the last segment of the body), wich are formed from modified accessory glands of the female reproductive system [8-10]. Ant species of the genus Odontomachus are particularly aggressive and their venoms have high toxic activity [3]. These ants produce various chemicals that are used for attack, defense and communication through volatile components in prey capture, protect the nest from predators and prevent the development of diseases in their colonies [11]. It is known that the venom comprises organic molecules such as proteins, lipids, vasoactive amines and a wide variety of different enzymes, such as phospholipases and hyaluronidases [12-17]. These substances are responsible for the toxicity of this venom and several of these components have pharmacological and therapeutic properties [18]. The mapping recent of the Tetramorium bicarinatum ant crude venom demonstrated the presence of different proteins, including toxin $(11 \%)$ and non-toxin $(3 \%)$ class proteins. With regard to toxin class, the authors observed a high diversification with the major part consistent with the classical hymenopteran venom protein signature represented by venom allergen (33.3\%), followed by a diverse toxin-expression profile including several distinct isoforms of phospholipase A1 and A2, venom serine protease, hyaluronidase, protease inhibitor and secapin [19].

Considering the essential role of insect proteases for survival and death of living organisms, along with the increasing importance as potential therapeutic targets, the aim of the present work was to investigate the biological and enzymatic characteristics of proteases present in the crude venom of the ant $O$. bauri.

\section{Results}

\subsection{Electrophoretic Profile}

The O. bauri crude venom samples from several extractions had a mean protein concentration of $715.0 \mu \mathrm{g} / \mathrm{mL}$. The SDS-PAGE profile of $O$. bauri crude venom showed several peptide components, with relative molecular masses $(\mathrm{Mr})$ ranging from 18 to $160 \mathrm{kDa}$ when analyzed under nonreducing conditions, with more intense staining for bands above $29 \mathrm{kDa}$ (Figure 1, lane 1). Under reducing conditions, the electrophoretic profile was changed, showing a wider $M r$ range, from 24 to $160 \mathrm{kDa}$, (Figure 1, lane 2).

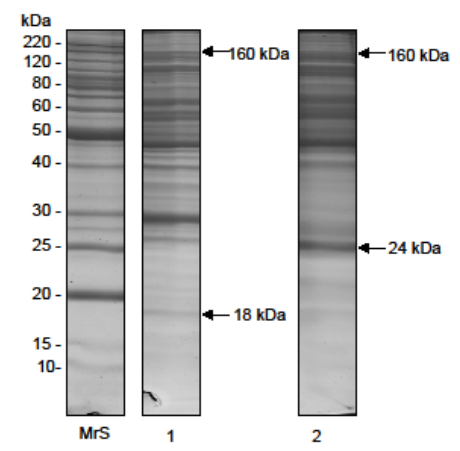

Figure 1. Electrophoretic profile of the O. bauri venom. Silver stained SDS-polyacrylamide gel at $14 \%$. Venom samples of $O$. bauri $(15 \mu \mathrm{g})$ were analyzed in non-reducing and reducing (2-mercaptoethanol) conditions. MrS: molecular size markers; lane 1, crude venom of O. bauri in non-reducing conditions; lane 2 , crude venom of $O$. bauri in reducing conditions. 


\subsection{Enzymatic Activities}

\subsubsection{Azocaseinolytic Activity}

The proteolytic activity of $O$. bauri crude venom on azocasein was determined as $102 \mathrm{U} / \mu \mathrm{g}$. When evaluating the effect at various $\mathrm{pH}$ the venom presented higher and optimal activity in $\mathrm{pH}$ 8.0, with a significant loss in acidic (4.0; 5.0 and 6.0) and basic (11.0) $\mathrm{pH}$ (Figure 2A). The effect of temperature in the proteolytic activity showed high activities between $25^{\circ} \mathrm{C}$ and $37^{\circ} \mathrm{C}$, with optimal activity at $37^{\circ} \mathrm{C}$ and significant reduction at higher temperatures (Figure 2B). In this way, the following experiments were performed at $37^{\circ} \mathrm{C}$ for one hour.

Concerning the effect of inhibitors, the proteolytic activity was significantly reduced after pre-incubation with aprotinin, leupeptin and EDTA. However, aprotinin allowed the highest reduction of the activity (45\%) when compared to other inhibitors as leupeptin (29\%) and EDTA (9\%) (Figure 2C). In contrast, the effect of ions as $\mathrm{Ca}^{2+}, \mathrm{Mg}^{2+}, \mathrm{Zn}^{2+}$ and $\mathrm{Cu}^{2+}$ did not show any change of the proteolytic activity (data not shown).
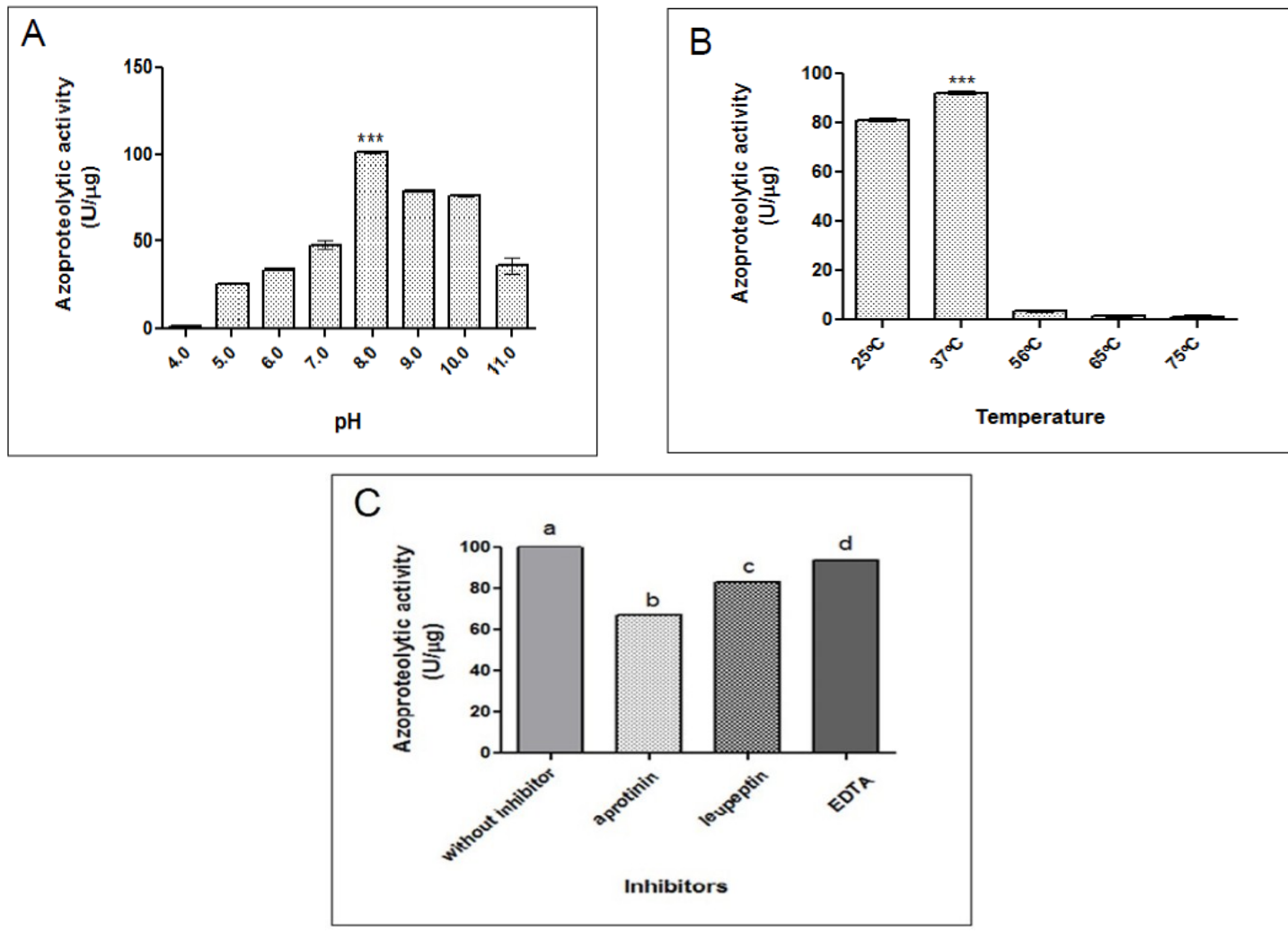

Figure 2. Influence of $\mathrm{pH}$, temperature and inhibitors on the proteolytic activity of the O. bauri crude venom on azocasein. (A) The crude extract $(1 \mu \mathrm{g})$ was preincubated at various ranges of $\mathrm{pH}$; (B) different temperature or (C) with different inhibitors $(5 \mathrm{mM})$ for $30 \mathrm{~min}$ and added to azocasein $\left(1 \mathrm{mg} / \mathrm{mL}\right.$ ) for $60 \mathrm{~min}$ at $37^{\circ} \mathrm{C}$. The azocaseinolytic activity was assayed at $405 \mathrm{~nm}$ and expressed in $\mathrm{U} / \mu \mathrm{g}$. Results are reported as mean \pm standard deviation. ${ }^{* *}$ Statistically significant differences in comparison to other ranges of $\mathrm{pH}$ or temperature $(p<0.0001)$. In $(\mathbf{C})$, different letters indicate statistically significant differences among the inhibitors $(p<0.05)$ (ANOVA and Bonferroni multiple comparison post-test).

\subsubsection{Gelatin Zymography}

The Zymogram method was used to determine the nature and the molecular weight of the gelatinolytic enzyme present in the venom of $O$. bauri. Figure 3 shows that the crude venom presented six proteins having gelatinolytic activity, with apparent molecular masses of 17, 20, 26, 29, 43 and 
$48 \mathrm{kDa}$ (Figure 3A). When the effect of different buffers and $\mathrm{pH}(4.0-10.0)$ in the gelatinolytic activity was evaluated, we observed increased renaturation of proteases with buffer containing $\mathrm{CaCl}_{2}$ and $\mathrm{NaCl}$ in the presence of the chemicals CHAPS and EDTA (Figure 3B) and with optimal $\mathrm{pH}$ of 8.0 (Figure 3C).

A

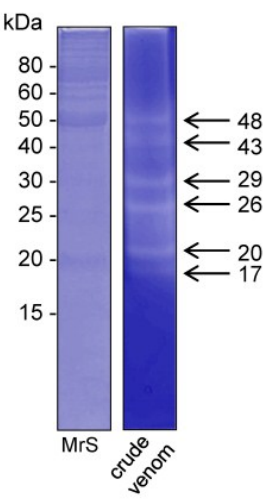

B
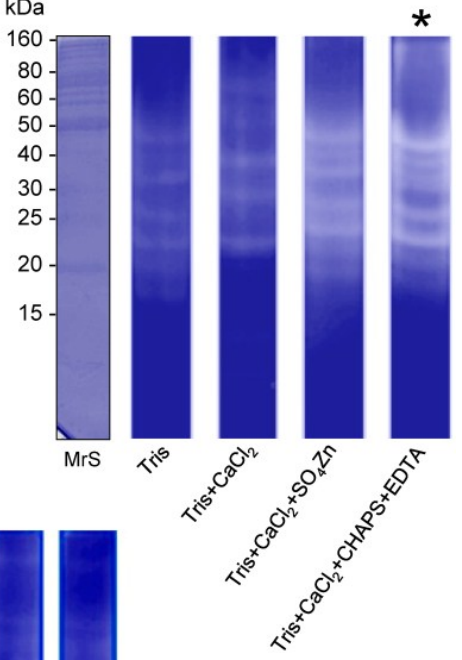

C $\mathrm{kDa}$

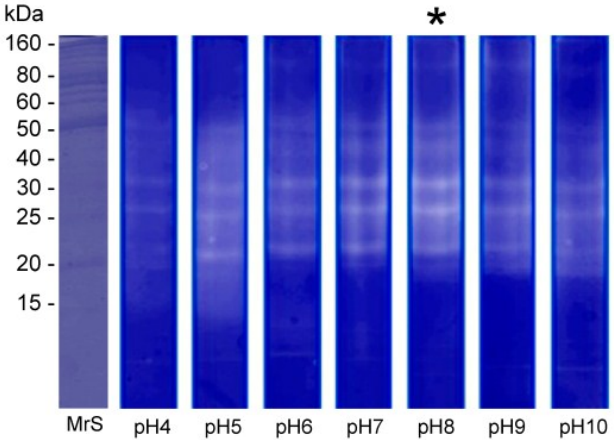

Figure 3. Acrylamide-gelatin gel zymography of the O. bauri venom. (A) Crude venom samples were analyzed in non-reducing conditions. MrS: molecular size markers; (B) Effect of different buffers (50 mM Tris- $\mathrm{HCl} ; 50 \mathrm{mM}$ Tris- $\mathrm{HCl}$ and $10 \mathrm{mM} \mathrm{CaCl}_{2} ; 50 \mathrm{mM}$ Tris- $\mathrm{HCl}, 1 \mathrm{mM} \mathrm{CaCl}{ }_{2}$ and $1 \mathrm{mM} \mathrm{SO}_{4} \mathrm{Zn}$; $50 \mathrm{mM}$ Tris- $\mathrm{HCl}, 150 \mathrm{mM} \mathrm{NaCl}, 10 \mathrm{mM} \mathrm{CaCl} 2,0.002 \%$ CHAPS and $10 \mathrm{mM}$ EDTA) on the gelatin proteolysis activity of the O. bauri venom; (C) Effect of different ranges of $\mathrm{pH}(4$ to 10$)$ on the gelatin proteolysis activity of the $\mathrm{O}$. bauri venom. $\left({ }^{*}\right)$ optimal buffer and $\mathrm{pH}$.

A $k D a$

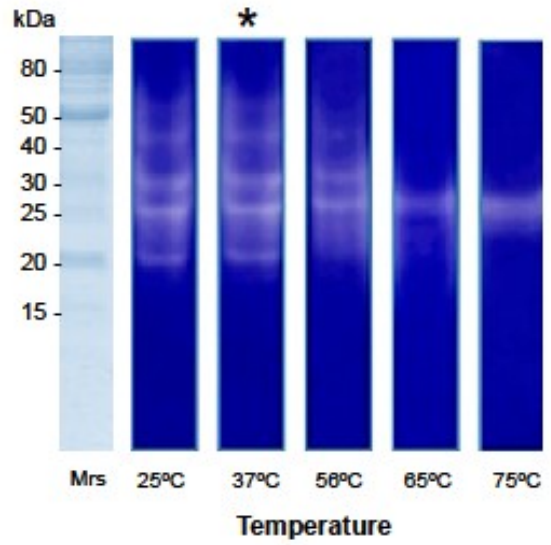

B

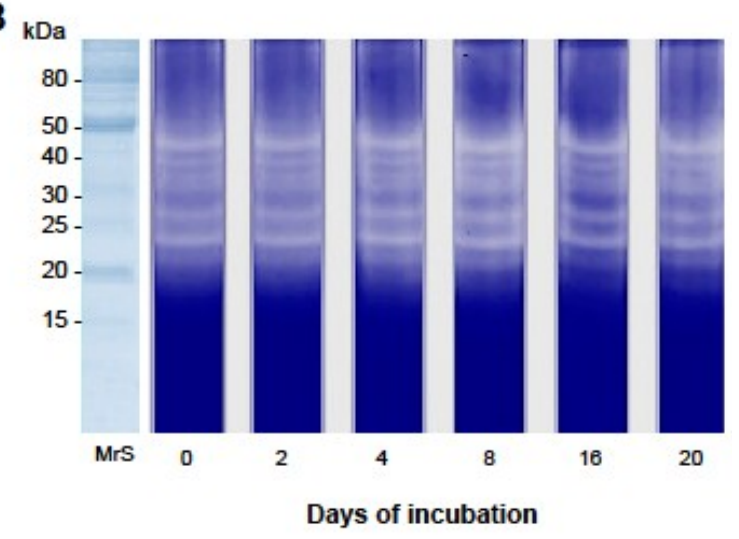

Figure 4. The temperature effect on the gelatin proteolysis activity of the O. bauri venom and enzyme stability. (A) Temperature-dependent gelatin zymography. Crude venom samples (5 $\mu \mathrm{g})$ were incubated at different temperatures for $30 \mathrm{~min}$. MrS: molecular size markers; $\left(^{*}\right)$ optimal temperature for enzymatic activity; (B) Enzyme stability. Crude venom samples were incubated at $4{ }^{\circ} \mathrm{C}$ in intervals from 2 to 20 days and applied to the gel of gelatinase activity. 
Temperature was also critical for gelatin proteolysis induced by the O. bauri crude venom, as we demonstrate that its activity was maintained between $25^{\circ} \mathrm{C}$ and $37{ }^{\circ} \mathrm{C}$ after $30 \mathrm{~min}$ of reaction. However, this activity was impaired when the temperature increased above $56{ }^{\circ} \mathrm{C}$ (Figure $4 \mathrm{~A}$ ). Enzyme stability was also evaluated, and showed that the $O$. bauri venom was constant until the 20th day of incubation at $4{ }^{\circ} \mathrm{C}$ (Figure 4B).

\subsubsection{Fibrinogenolytic Activity}

Crude venom of $O$. bauri showed a time-dependent fibrinogenolytic activity. The enzymes completely degraded bovine fibrinogen $\alpha$-chain at a concentration of $5 \mu \mathrm{g}$ and with $30 \mathrm{~min}$ of incubation. However, degradation of fibrinogen $\beta$-chain was observed with longer incubation time (720 $\mathrm{min}$ ) and on the other hand, the enzymes did not showed any activity over fibrinogen $\gamma$-chain (Figure 5).

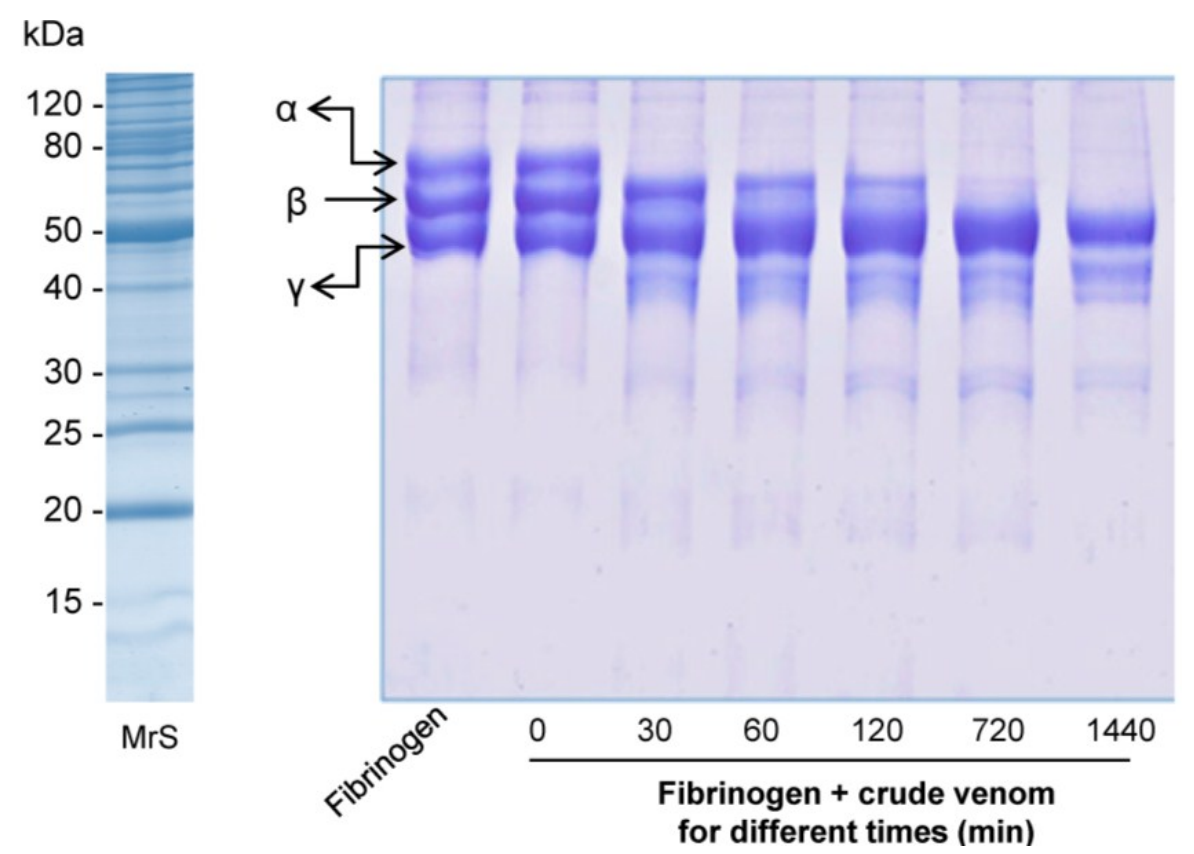

Figure 5. Proteolysis of bovine fibrinogen by the O. bauri crude venom. Fibrinogen was incubated or not with $5 \mu \mathrm{g}$ of the crude venom of $O$. bauri at $37^{\circ} \mathrm{C}$ for $0,30,60,120,720(12 \mathrm{~h})$ and $1440(24 \mathrm{~h}) \mathrm{min}$ and then analyzed on SDS-PAGE (14\%). MrS: molecular size markers; bovine fibrinogen chains $(\alpha, \beta$, and $\gamma$ ) are shown on the left.

\subsection{Biological Activities}

\subsubsection{Hemolytic Activity}

The hemolytic activity of $O$. bauri crude venom was verified in different concentrations, reaching a maximal hemolytic activity (around 100\% lysis) from the concentration from 60 to $180 \mu \mathrm{g} / \mathrm{mL}$ $(p<0.01)$ (Figure 6A).

\subsubsection{Cell Viability Assay}

Viability of HeLa cells and murine bone marrow-derived macrophages (BMDM) in the presence of different concentrations of $O$. bauri crude venom (Figure $6 \mathrm{~B}$ ) was above $63 \%$ and $85 \%$, respectively, even when the highest concentrations ( 30 and $60 \mu \mathrm{g} / \mathrm{mL}$ ) were used. 

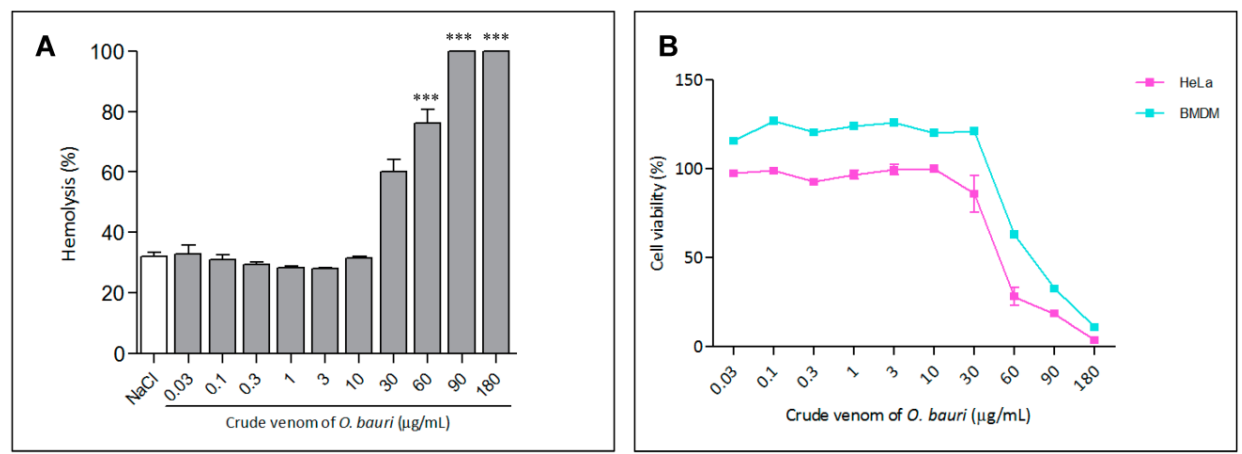

Figure 6. Hemolytic activity and in vitro cytotoxicity. (A) Red blood cells were incubated with different concentrations $(0.06$ to $32 \mu \mathrm{g} / \mathrm{mL})$ of the crude venom or $1 \%(v / v)$ Triton X-100 (total lysis) or in the presence of $0.9 \% \mathrm{NaCl}$ (spontaneous lysis). Absorbance was measured at $540 \mathrm{~nm}$ and results $($ mean $\pm \mathrm{SD})$ are reported as percentage of hemolysis in relation to total lysis. ${ }^{* * *} p<0.0001$ in relation to $\mathrm{NaCl}$ control (ANOVA and Dunett post-test); (B) HeLa cells and murine bone-marrow-derived macrophages were separately cultured in 96-well plates in the absence (control) or presence of different concentrations of the $O$. bauri crude venom $(0.03,0.1,0.3,1,3,10,30,60,90$ and $180 \mu \mathrm{g} / \mathrm{mL}$ ) for $24 \mathrm{~h}$. The results were expressed as the percentage of viable cells in relation to the control.

\subsubsection{Hemorrhagic and Coagulant Activities}

The crude extract of $O$. bauri was also evaluated for hemorrhagic and coagulant activities. There was no formation of minimum hemorrhagic lesion (above $10 \mathrm{~mm}$ of diameter) in Swiss mice inoculated intradermally with the crude venom, even using high concentration $(50 \mu \mathrm{g})$. However, the O. bauri venom was able to coagulate bovine plasma in about $15 \mathrm{sec}$ when compared to the positive control containing $0.2 \mathrm{M} \mathrm{CaCl}_{2}$ (coagulation in about $2 \mathrm{~min}$ ) (data not shown).

\subsubsection{Defibrinating Activity}

Crude venom of $O$. bauri caused defibrinogenation when administered intraperitoneally to mice, making the plasma uncoagulable. Animals treated with the venom promoted blood clotting after $4.3 \mathrm{~min}$ while the control animals had average clotting time of $1.6 \mathrm{~min}(p<0.01)$ (data not shown).

\subsubsection{Antimicrobial Activity}

The antimicrobial activity of the O. bauri crude venom was also examined and the results were measured by the zones of bacterial growth inhibition around each of the disks, comparing with positive controls. O. bauri crude venom presented antimicrobial activity against both Gram-negative (E. coli) and Gram-positive (S. aureus) bacteria in the concentration of $15 \mu \mathrm{g} /$ disk, with inhibition of bacterial growth in $62.5 \%$ and $72.7 \%$, respectively, when compared to positive controls (Table 1 ).

Table 1. Antimicrobial activities of the Odontomachus bauri crude venom by using the agar diffusion technique.

\begin{tabular}{ccc}
\hline \multirow{2}{*}{ O. bauri Venom Concentration $(\mu \mathrm{g})$} & \multicolumn{2}{c}{ Zones of Growth Inhibition, in mm (\% Inhibition) } \\
\cline { 2 - 3 } & Escherichia coli & Staphylococcus aureus \\
\hline 15 & $15(62.5)$ & $16(72.7)$ \\
10 & $12(50.0)$ & $14(63.6)$ \\
5 & $11(45.8)$ & $11(50.0)$ \\
2.5 & 0 & 0 \\
1.25 & 0 & 0 \\
0.6 & 0 & 0 \\
0.3 & 0 & 0 \\
Positive control ${ }^{*}$ & 24 & 22 \\
\hline \multicolumn{4}{c}{}
\end{tabular}




\subsubsection{Antiparasitic Activity}

Effect of the O. bauri crude venom on T. gondii infection and replication in HeLa cells was verified and shown in Figure 7. The pretreatment of T. gondii tachyzoites with O. bauri venom before infection of HeLa cells showed a dose-response inhibitory curve that reached up to $83 \%$ of inhibition and showed an $\mathrm{IC}_{50}$ of $12.2 \mu \mathrm{g} / \mathrm{mL}$ for the infection index (Figure 7A). Concerning the inhibition of intracellular parasite replication, the pretreatment of T. gondii tachyzoites with O. bauri before infection of HeLa cells showed a dose-dependent inhibition, reaching rates of $68 \%$ and $\mathrm{IC}_{50}$ of $35.1 \mu \mathrm{g} / \mathrm{mL}$ (Figure 7B).

A

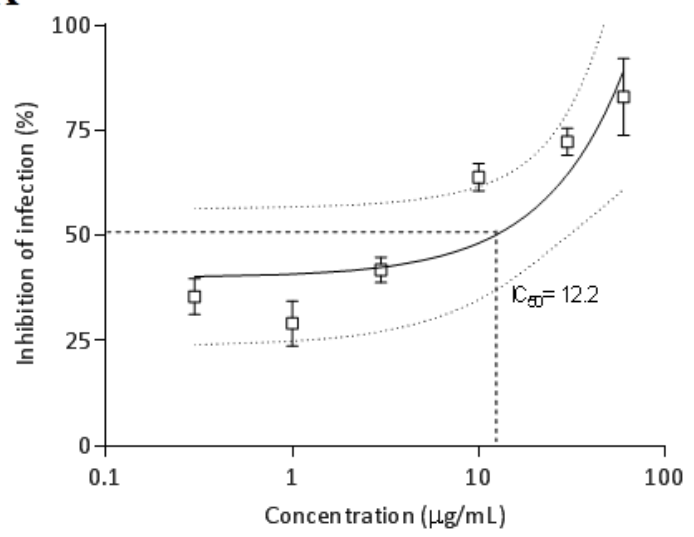

B

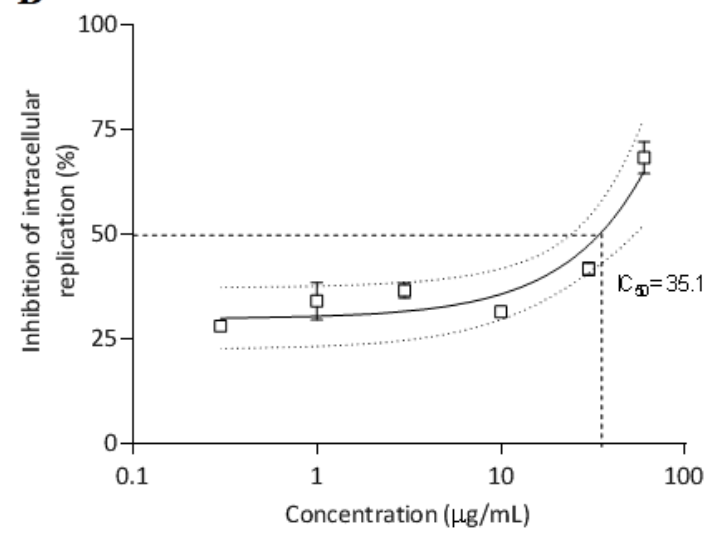

Figure 7. Effect of pretreatment of $T$. gondii tachyzoites with $O$. bauri crude venom in different concentrations $(0.3,1,3,10,30$ and $60 \mu \mathrm{g} / \mathrm{mL}$ ) or with medium alone (control) (A) on T. gondii infection and (B) intracellular replication in HeLa cells. Results are expressed as mean (box) and standard deviation of the percentages of inhibition of infection and intracellular replication related to controls. Dotted lines show the inhibitory concentration of $50 \%\left(\mathrm{IC}_{50}\right)$.

\section{Discussion}

Hymenoptera venoms constitute a number of pharmacologically active biomolecules, from which the most common components are low molecular weight proteins recognized as important allergens and resulting in an IgE-mediated reaction [20-22]. The discovery of such natural toxins may lead to the identification of model compounds for the development of novel therapeutic agents [23]. In that sense, we evaluated the role of the crude venom of the ant $O$. bauri, concerning their biological and enzymatic characteristics.

First, the electrophoretic profile of the $O$. bauri crude venom revealed several peptide bands between 18 and $160 \mathrm{kDa}$. Insect venoms contain numerous proteins with or without enzymatic activity, and usually have abundant protein profiles. Previous studies reported that crude venoms of other species of ants, such as Solenopsis invicta and Myrmecia pilosula, also exhibited an extensive electrophoretic profile with bands ranging from 10 to $232 \mathrm{kDa}[10,24,25]$.

Second, the effect of $\mathrm{pH}$ on the proteolytic activity of the crude venom on azocasein substrate was evaluated, showing an optimal activity at $\mathrm{pH}$ 8.0. Similar results were found in other species of Hymenoptera. Whitwort et al. [26] found an optimum $\mathrm{pH}$ of 8.0 for a protease isolated from the larvae of ant Solenopsis invicta, and observed ability of gelatin and azocasein degradation by the enzymes of the venom. The evaluation of the effect of temperature on the gelatin proteolysis activity of the crude venom showed high activities between $25^{\circ} \mathrm{C}$ and $37^{\circ} \mathrm{C}$, optimal activity at $37^{\circ} \mathrm{C}$ and impaired activity above $56{ }^{\circ} \mathrm{C}$. Qiu et al. [27] reported optimum temperature at $30{ }^{\circ} \mathrm{C}$ for a serine protease isolated from the venom of bee Bombus terrestris. Above this temperature the enzyme activity declined sharply, because high temperatures can cause protein denaturation [28]. 
The enzymatic activity of the $O$. bauri crude venom in the presence of different protease inhibitors (EDTA, leupeptin, and aprotinin) showed significant reduction under effect of these inhibitors, particularly aprotinin, suggesting that the crude venom presents serine proteases in greater intensity or alternatively, this could also be indicative of potent proteolytic activity of the serine proteases. According to Bouzid et al. [29] some proteins/enzymes present in the venom of ant Tetramorium bicarinatum are components such as sialidase, prophenoloxidase and serine protease. Snake venom proteolytic enzymes are generally composed by two major groups: serine proteases and metalloproteases. Recent work demonstrated that the proteolytic activity of serine proteases Da-36 of the Deinagkistrodon acutus snake venom was strongly reduced by the inhibitor PMSF and moderately affected by benzamidine and aprotinim [30].

The crude venom of $O$. bauri also presented gelatinolytic activity as determined by the zymogram method, showing proteins with apparent molecular masses ranging from 17 to $48 \mathrm{kDa}$. Assays of the effect of different buffers and $\mathrm{pH}$ in the gelatinolytic activity showed increased renaturation of proteases with the use of buffers containing $\mathrm{CaCl}_{2}$ and $\mathrm{NaCl}$ in the presence of CHAPS and EDTA and optimal $\mathrm{pH}$ at 8.0. Previous studies reported that the detergent CHAPS and the ionic strength generated by $\mathrm{NaCl}$ can modulate the activity and stability of some proteins [31].

The fibrinogenolytic activity assay showed that the enzymes of the $O$. bauri crude venom were able to degrade the fibrinogen $\alpha$-chain and $\beta$-chain, while the fibrinogen $\gamma$-chain remained unchanged, suggesting that these enzymes may be grouped as $\alpha$ and $\beta$ class fibrinogenases. Similar results demonstrated that serine protease isoenzymes purified of the Daboia russelii russelii snake venom preferentially cleaved $\alpha$-chain of fibrinogen with a lower activity towards fibrinogen $\beta$-chain [32].

Concerning the biological activities, the crude venom of $O$. bauri showed cytotoxic effects for HeLa cells and BMDM by MTT assays and maximal hemolytic activity, only when administered in high concentration $(60 \mu \mathrm{g} / \mathrm{mL})$. The ability to cause lyses and hemolysis appears to be physiologically important, suggesting that the enzymes present in the venom interact with cell membranes and cause disorder in their organization, leading to rupture [33]. Venom of some ants of the subfamily Ponerinae such as Dinoponera grandis, Platythyrea. cribinodis, araponeractatomma and Odontomachus hematodus exhibit hemolytic activity; however, this activity is low compared to other Hymenoptera venoms, such as those of the social wasps [34,35].

When studying the hemorrhagic activity of the O. bauri crude venom, the enzymes were not able to degrade proteins from extracellular matrix of basal endothelial cells and consequently induce hemorrhagic lesions. The absence of hemorrhagic activity was verified in venoms of other ant species, such as Pogonomyrmex barbatus and Paraponera clavata and wasps, such as Vespula pensylvanica and Polystes flavus [36]. On the other hand, the crude venom of $O$. bauri showed coagulant activity in vitro and defibrinating activity in vivo, allowing future studies on thrombolytic diseases. Enzymes with anticoagulant properties have been described for some ant venoms, such as Pogonomyrmex barbatus, wasps as Vespula pensylvanica, Polystes flavus [36] and Vespa magnifica [37] as well as snakes like Bothrops [38]. Serine proteases generally cause defibrinating activity in vivo, as observed in the Bothrops asper snake venom, but also are able of promote blood clotting in vitro [39].

The O. bauri crude venom showed antimicrobial activity against S. aureus and E. coli, supporting the biological activity of its enzymatic compounds. Recent studies have demonstrated that ant Myrmecia pilosula peptides exhibited moderate antimicrobial activity against Escherichia coli and Staphylococcus aureus [10]. The antimicrobial activity of mastoparans, a family of small peptides identified from the venom of hymenopteroid insects, has been reported [40], due to interaction between the positively and negatively charged microbial membranes. This is the first report of the activity of the O. bauri venom against both Gram-positive and Gram-negative bacteria, although the actual antimicrobial mechanism is still unclear.

Finally, the O. bauri venom also showed antiparasitic activity on T. gondii infection in vitro. The pretreatment of $T$. gondii tachyzoites with the venom before infection of HeLa cells was able to control 
the infection, as demonstrated by dose-dependent inhibition curves and considerably low $\mathrm{IC}_{50}$ values. Similar effect was observed concerning the dose-dependent inhibition of parasite intracellular replication. These findings indicate that the O. bauri crude venom showed to be effective when tested directly against the parasite, with more reduction in the infection index than the parasite replication. A recent study reported that Bungarus caeruleus snake venom (BCV) possessed anti-leishmanial activity against promastigotes and amastigotes of Leishmania donovani, with $\mathrm{BCV} \mathrm{IC}_{50}$ values of $14.5 \mu \mathrm{g} / \mathrm{mL}$ and $11.2 \mu \mathrm{g} / \mathrm{mL}$, respectively [41].

\section{Experimental Section}

\subsection{Animals}

Male Swiss mice (18-22 g) were kept in the Bioterism Center and Animal Experimentation, Federal University of Uberlândia, MG, Brazil. All procedures were conducted according to guidelines for animal ethics and the study received approval of the Ethics Committee for Animal Experimentation of the institution (protocol number 059/14).

\subsection{Crude Venom}

The ants (O. bauri) were collected in Uberlândia city, Minas Gerais state, Brazil, and immediately frozen and stored at $-20^{\circ} \mathrm{C}$. The venom gland of $O$. bauri was obtained by removing the sting apparatus with an entomological forceps, grabbing the last segment of the abdomen and detaching it, along with the sting apparatus. The venom samples were extracted from a quantity of 10 ants, solubilized with physiological saline solution $(0.9 \% \mathrm{NaCl}$, Sigma-Aldrich, St. Louis, MO, USA) and centrifuged at $13,000 \times \mathrm{g}$ for $10 \mathrm{~min}$. Venom protein concentrations were determined by the method of [42], using bovine serum albumin as standard.

\subsection{Polyacrylamide Gel Electrophoresis (SDS-PAGE)}

The gels were prepared using the system of discontinuous buffer described by Laemmli [43]. The stacking gel was prepared with $4 \%$ acrylamide-bisacrylamide (Sigma-Aldrich, St. Louis, MO, USA), whereas for the separating gel a concentration of $12 \%$ was used. Venom samples (20 $\mu \mathrm{g})$ were loaded by track in gels. Gels were run under both reducing (with $\beta$-mercaptoethanol, Sigma-Aldrich) and non-reducing conditions. Proteins were stained with a solution of Coomassie blue R-250 (Sigma-Aldrich). Molecular size markers (MrS) (BenchaMarckTM Protein Ladder, Invitrogen, Carlsbad, CA, USA) were used in each electrophoretic run.

\subsection{Enzymatic Activities}

\subsubsection{Azocaseinolytic Activity}

Proteolytic activity of the O. bauri venom was determined using azocasein (Sigma-Aldrich) as substrate [44] with modifications. Aliquots of $1 \mu \mathrm{g}$ of venom were added to a mixture of $500 \mu \mathrm{L}$ of $50 \mathrm{mM}$ Tris- $\mathrm{HCl}$ (Sigma-Aldrich) $\mathrm{pH} 6.8$ and $500 \mu \mathrm{L}$ of $2 \%$ azocasein solution $(w / v)$. As negative control, $500 \mu \mathrm{L}$ of saline solution were added to $500 \mu \mathrm{L}$ of $2 \%$ azocasein solution. After $1 \mathrm{~h}$ of incubation at $37^{\circ} \mathrm{C}$ the reaction was stopped by adding $100 \mu \mathrm{L}$ of $15 \%$ trichloroacetic acid (TCA, Sigma-Aldrich) and the samples were centrifuged at $10,000 \times g$ for $10 \mathrm{~min}$. One unit of activity was defined as an increase of 0.01 in absorbance units at $405 \mathrm{~nm}$, and the results were expressed as specific activity units $(\mathrm{U} / \mathrm{mg})$.

\subsubsection{Effect of $\mathrm{pH}$ and Temperature on Azocaseinolytic Activity}

To study the effect of $\mathrm{pH}$ on azocaseinolytic activity, $1 \mu \mathrm{g}$ of venom was added to $500 \mu \mathrm{L}$ of $2 \%$ azocasein solution buffered with $500 \mu \mathrm{L}$ of the following buffers at various $\mathrm{pH}$ ranges: $0.2 \mathrm{M}$ sodium acetate (Sigma-Aldrich) pH 4.0 and pH 5.0; 0.2 M sodium phosphate (Sigma-Aldrich) pH 6.0; $0.2 \mathrm{M}$ 
Tris- $\mathrm{HCl} \mathrm{pH} 7.0$ and $\mathrm{pH}$ 9.0; 0.2 M sodium borate (Sigma-Aldrich) $\mathrm{pH}$ 10.0; 0.2 M phosphate sodium (Sigma-Aldrich) $\mathrm{pH}$ 11.0.

The effect of temperature on the azoproteolytic activity was verified by preheating for $15 \mathrm{~min}$ $1 \mu \mathrm{g}$ of venom at temperatures ranging from $25^{\circ} \mathrm{C}$ to $75^{\circ} \mathrm{C}$, following incubation with $2 \%$ azocasein solution. The reactions were stopped by adding $100 \mu \mathrm{L}$ of $15 \% \mathrm{TCA}$, followed by centrifugation and the absorbance read in a spectrophotometer at $405 \mathrm{~nm}$.

\subsubsection{Effect of Inhibitors and Ions on Azocaseinolytic Activity}

The stability of enzymes of the $O$. bauri venom was evaluated on the basis of its proteolytic activity on azocasein in the presence of different protease inhibitors as aprotinin (serine proteases, Sigma-Aldrich), leupeptin (cysteine proteases, Sigma-Aldrich) and EDTA (metalloproteases, Sigma-Aldrich) and bivalent ions $\left(\mathrm{Ca}^{2+}, \mathrm{Mg}^{2+}, \mathrm{Zn}^{2+}\right.$ and $\left.\mathrm{Cu}^{2+}\right)$, all reagents at concentration of $5 \mathrm{mM}$. Aliquots of $1 \mu \mathrm{g}$ of venom and $5 \mu \mathrm{L}$ of inhibitors or ions were preincubated for $15 \mathrm{~min}$ and then solubilized in $2 \%$ azocasein solution. After $1 \mathrm{~h}$ of incubation the reaction was stopped and the enzymatic activity determined as above described.

\subsubsection{Gelatin Zymography}

The technique described by [45], with some modifications, was employed, using gelatin as substrate. Crude venom samples $(5 \mu \mathrm{g})$ were separated by $12 \%$ SDS-PAGE containing $1 \%$ of the gelatin substrate (Sigma-Aldrich). Subsequent to the electrophoresis, the gel was washed twice for $30 \mathrm{~min}$ at room temperature in 2.5\% Triton X-100 (Sigma-Aldrich) to remove the SDS and incubated at $37{ }^{\circ} \mathrm{C}$ for $18 \mathrm{~h}$ in one of the following buffers: $0.05 \mathrm{M}$ sodium citrate $\mathrm{pH} 4.0, \mathrm{pH} 5.0$ and $\mathrm{pH}$ 6.0; $0.05 \mathrm{M}$ Tris- $\mathrm{HCl} \mathrm{pH} \mathrm{7.0,} \mathrm{pH} 8.0, \mathrm{pH} 9.0$ and $\mathrm{pH} 10.0$; and in the presence of ions and other chemicals as $50 \mathrm{mM}$ Tris- $\mathrm{HCl} \mathrm{pH}$ 8.0; $50 \mathrm{mM}$ Tris- $\mathrm{HCl}$ and $10 \mathrm{mM} \mathrm{CaCl}_{2}$ (Sigma-Aldrich) $\mathrm{pH}$ 8.0; $50 \mathrm{mM}$ Tris-HCl, $150 \mathrm{mM} \mathrm{NaCl}, 10 \mathrm{mM} \mathrm{CaCl} 2,0.002 \%$ CHAPS (Sigma-Aldrich) and $10 \mathrm{mM}$ EDTA pH 8.0; and $50 \mathrm{mM}$ Tris-HCl, $1 \mathrm{mM} \mathrm{CaCl}_{2}$ and $1 \mathrm{mM} \mathrm{ZnSO}_{4}$ (Sigma-Aldrich) $\mathrm{pH}$ 8.0. The gels were stained with R-250 Coomassie blue and gelatin proteolysis activity detected as colorless bands in the otherwise blue gel.

\subsubsection{Temperature Dependent Gelatinolytic Activity}

The thermal effect on the gelatin proteolysis activity of the $O$. bauri venom was investigated at temperatures from $25{ }^{\circ} \mathrm{C}$ to $75^{\circ} \mathrm{C}$. First, aliquots $(20 \mu \mathrm{g})$ were incubated at different temperatures $\left(25^{\circ} \mathrm{C}, 37^{\circ} \mathrm{C}, 56{ }^{\circ} \mathrm{C}, 65{ }^{\circ} \mathrm{C}\right.$ and $75^{\circ} \mathrm{C}$ ) for $30 \mathrm{~min}$ and applied to the gel of gelatinase activity. After electrophoresis, the gel was incubated with $50 \mathrm{mM}$ Tris- $\mathrm{HCl}, 150 \mathrm{mM} \mathrm{NaCl}, 10 \mathrm{mM} \mathrm{CaCl}_{2}, 0.002 \%$ CHAPS and $10 \mathrm{mM}$ EDTA (pH 8.0) for $18 \mathrm{~h}$ and stained with Coomassie blue.

\subsubsection{Enzyme Stability}

To analyze the enzyme stability, $200 \mu \mathrm{L}$ of the $O$. bauri venom (stock solution at $500 \mu \mathrm{g} / \mathrm{mL}$ ) was incubated at $4{ }^{\circ} \mathrm{C}$ in intervals from 2 to 20 days. At each day of incubation, aliquots of $10 \mu \mathrm{L}(5 \mu \mathrm{g})$ were removed and applied to the gel of gelatinase activity as above described.

\subsubsection{Fibrinogenolytic Activity}

The fibrinogenolytic activity of the O. bauri venom was determined in SDS-PAGE according to the methodology of [46], with modifications. Briefly, $25 \mu \mathrm{L}$ of bovine fibrinogen (stock solution at $3 \mathrm{mg} / \mathrm{mL}$, Sigma-Aldrich) were incubated with $5 \mu \mathrm{g}$ of the venom at $37^{\circ} \mathrm{C}$. At different time intervals (30, 60, 120, 720 and $1440 \mathrm{~min}$ ), aliquots were collected and the reaction was stopped by adding SDS sample buffer. The hydrolysis profile was followed by SDS-PAGE at $12 \%$ gel [43]. 


\subsection{Biological Activities}

\subsubsection{Hemolytic Activity}

Red blood cells of Swiss mice were used to evaluate the hemolytic activity of the crude venom of O. bauri according to [47] with modifications. After collected the red blood cells were washed twice with $0.9 \% \mathrm{NaCl}(w / v)$ and $0.5 \%$ erythrocytes $(v / v)$ were incubated at $37^{\circ} \mathrm{C}$ in the presence of venom (32 to $0.06 \mu \mathrm{g}$ ) for $1 \mathrm{~h}$. Samples were then centrifuged $(450 \times \mathrm{g}$ for $5 \mathrm{~min}$ ), and the absorbance of the supernatants was measured at $540 \mathrm{~nm}$. The absorbance measured from lysed red blood cells in presence of $1 \%(v / v)$ Triton X-100 was considered as $100 \%$.

\subsubsection{Cell Viability Assay}

Cytotoxicity of $O$. bauri crude venom was assessed by determining cellular viability using MTT assay as previously described [48]. HeLa cells and BMDM from Swiss mice were cultured separately in 96-well plates $\left(1 \times 10^{5}\right.$ cells/well) in triplicate, in the presence of $O$. bauri crude venom in different concentrations $(0.03,0.1,0.3,1,3,10,30,60,90$ and $180 \mu \mathrm{g} / \mathrm{mL})$. As controls, cells were incubated with complete RPMI medium alone. After $24 \mathrm{~h}$ of incubation at $37^{\circ} \mathrm{C}$ and $5 \% \mathrm{CO}_{2}$, cells were washed and pulsed with $10 \mu \mathrm{L}$ of thiazolyl blue at $5 \mathrm{mg} / \mathrm{mL}$ in $90 \mu \mathrm{L}$ of complete RPMI medium $4 \mathrm{~h}$ prior to the end of the culture. Formazan particles were solubilized in $10 \%$ sodium dodecyl sulfate (SDS) and $50 \% \mathrm{~N}, \mathrm{~N}$-dimethyl formamide (Sigma-Aldrich). The optical density was read after $30 \mathrm{~min}$ at $570 \mathrm{~nm}$ in a plate reader (Titertek Multiskan Plus, Flow Laboratories, McLean, VA, USA). Results were expressed as percentage of cell viability in relation to controls.

\subsubsection{Hemorrhagic Activity}

The hemorrhagic activity was assessed according to [36]. Samples containing $50 \mu \mathrm{g}$ of the crude venom of $\mathrm{O}$. bauri were prepared in $0.9 \% \mathrm{NaCl}$ and injected intradermally into the dorsal skin of Swiss mice, and saline solution alone was used as negative control. Three hours after the injection, the animals were sacrificed by cervical dislocation and the dorsal skin was removed. The minimum hemorrhagic dose (MHD) was defined as the amount of protein that induced a hemorrhagic lesion of $10 \mathrm{~mm}$ of diameter, as calculated using the perpendicular major diameters of the hemorrhagic spot.

\subsubsection{Coagulant Activity}

The coagulant activity of venom was assessed on citrated bovine plasma as described by Denson et al. [49], with modifications. Samples of $20 \mu \mathrm{g}$ of the crude venom of O. bauri were added to aliquots of $200 \mu \mathrm{L}$ of bovine plasma and incubated at $37^{\circ} \mathrm{C}$. The activity was characterized by the immediate appearance of fibrin network compared with the clotting time of the control containing $0.2 \mathrm{M} \mathrm{CaCl}_{2}$.

\subsubsection{Defibrinating Activity}

The defibrinating activity of venom was tested by the method of [50], with modifications. The activity was assessed by intraperitoneal injection of $2 \mu \mathrm{g} / \mathrm{g}$ body weight of mice of the O. bauri crude venom in $100 \mu \mathrm{L}$ of saline solution into male Swiss mice (18-22 g), using three mice per group; control animals received $200 \mu \mathrm{L}$ of saline solution. After one hour, the animals were anesthetized and submitted to cardiac puncture. Blood was placed in tubes and kept at $25-30{ }^{\circ} \mathrm{C}$ until clotting occurred. The minimum defibrinating dose (MDD) was defined as the amount of venom able to prevent coagulation.

\subsubsection{Antimicrobial activity}

The antimicrobial activity of the $O$. bauri venom was performed by the disk diffusion susceptibility method according to Yagmur et al. [51], with modifications, by applying a bacterial 
inoculum of approximately $2 \times 10^{8} \mathrm{CFU} / \mathrm{mL}$ to the surface of a large (150 $\mathrm{mm}$ diameter) Mueller-Hinton agar plate. Bacteria specimens tested included a Gram-positive, Staphylococcus aureus (ATCC 25923) and a Gram-negative, Escherichia coli (ATCC 25922). Paper filter disks (0.5 mm diameter) were prepared with crude venom of $O$. bauri in the following concentrations: $15,10,5,2.5$, $1.25,0.6$ and $0.3 \mu \mathrm{g}$ per disk unit; and placed on the inoculated agar surface. Commercially-prepared disks were used as positive control for S. aureus (Oxacillin; $1 \mu \mathrm{g}$, Laborclin, Pinhais, Brazil) and E. coli (Ampicillin; $10 \mu \mathrm{g}$, Laborclin). Sterile water disks as negative control were applied to both bacteria. Plates were incubated for $16-24 \mathrm{~h}$ at $35^{\circ} \mathrm{C}$ prior to determination of results by measuring the zones of growth inhibition around each of the disks.

\subsubsection{Antiparasitic Activity}

The antiparasitic activity of the O. bauri venom was verified on in vitro T. gondii infection following the protocols of de Oliveira et al. [52]. HeLa cells were cultured on 13-mm round glass coverslips into 24 -well plates $\left(1 \times 10^{5}\right.$ cells/well $\left./ 200 \mu \mathrm{L}\right)$ for $24 \mathrm{~h}$ at $37{ }^{\circ} \mathrm{C}$ and $5 \% \mathrm{CO}_{2}$. T. gondii tachyzoites (RH strain) were obtained from previously infected HeLa cells, washed in RPMI medium and pretreated for $1 \mathrm{~h}$ at $37^{\circ} \mathrm{C}$ and $5 \% \mathrm{CO}_{2}$ with crude venom of $O$. bauri in different concentrations $(0.3,1,3,10,30$ and $60 \mu \mathrm{g} / \mathrm{mL}$ ) or with medium alone (control). Next, parasites were washed and incubated with HeLa cell monolayers on coverslips at 2:1 (parasite: host cell) rate of infection $\left(2 \times 10^{5}\right.$ tachyzoites/well/200 $\left.\mu \mathrm{L}\right)$ for $24 \mathrm{~h}$ at $37{ }^{\circ} \mathrm{C}$ and $5 \% \mathrm{CO}_{2}$. Cells were washed with $0.9 \%$ $\mathrm{NaCl}$ to remove non-adherent parasites, fixed in 10\% buffered formalin for $2 \mathrm{~h}$ and stained with $1 \%$ toluidine blue (Sigma-Aldrich) for $5 \mathrm{~s}$. Coverslips were mounted on glass slides and cells were examined under a light microscope with regards to T. gondii infection index (percentage of infected cells per 100 examined cells) and parasite intracellular replication (mean number of parasites per cell in 100 infected cells).

Results were expressed as percentages of inhibition of infection as well as of parasite intracellular replication for each treatment in relation to controls. The median inhibitory concentration (IC50) of venom was calculated by extrapolation of the corresponding dose-curve response on a log linear plot employing the portions of the curve that transected the $50 \%$ response point [53].

\subsection{Statistical Analysis}

Statistical analysis was carried out using the GraphPad Prism 6.0 software (1992-2012, Graphpad Sofware Inc., San Diego, CA, USA). The azocasein proteolytic activity data were analyzed by one-way ANOVA and Bonferroni multiple comparison post-test. The hemolytic activity data were analyzed by one-way ANOVA and Dunett post-test. The anticoagulant activity data were analyzed by the Student's $t$-test. Values of $p<0.05$ were considered statistically significant.

\section{Conclusions}

In conclusion, the present investigation describes biological and enzymatic characterization of the crude venom of $O$. bauri. The properties of the venom here reported indicate that it possesses enzymes belonging to $\alpha$-fibrinogenase and demonstrates multifunctional activities, such as hemolytic, coagulant, defibrinating, antimicrobial and antiparasitic activities. This study may open interesting new structure-activity relationship perspectives for enzymes purified of the O. bauri crude venom with pharmacological interest for future studies related to infectious diseases.

Acknowledgments: The authors thank Ana Claudia Arantes Marquez Pajuaba, Marley Dantas Barbosa, Murilo Vieira da Silva and Zilda Mendonça da Silva Rodrigues for technical assistance. This work was supported by Brazilian Funding Agencies (CNPq, FAPEMIG and CAPES).

Author Contributions: M.F.S., C.M.M., V.S.M. and M.C.S. performed the experiments; F.M.S. conceived and designed the experiments; K.S.C.N., F.O., T.W.P.M. and F.M.S. analyzed the data; D.A.O.S. and F.M.S. wrote the paper.

Conflicts of Interest: The authors declare no conflict of interest. 


\section{References}

1. Spagna, J.C.; Vakis, A.I.; Schmidt, C.A.; Patek, S.N.; Zhang, X.; Tsutsui, N.D.; Suarez, A.V. Phylogeny, scaling, and the generation of extreme forces in trap-jaw ants. J. Exp. Biol. 2008, 211, 2358-2368. [CrossRef] [PubMed]

2. Jesus, M.S.; Rodrigues, W.C.; Barbosa, G.; Trilles, L.; Wanke, B.; Lazera Mdos, S.; Silva, M. Cryptococcus neoformans carried by Odontomachus bauri ants. Mem. Inst. Osvaldo Cruz 2012, 107, 466-469. [CrossRef]

3. Rodriguez-Acosta, A.; Reyes-Lugo, M. Severe human urticaria produced by ant (Odontomachus bauri, Emery 1892) (Hymenoptera: Formicidae) venom. Int. J. Dermatol. 2002, 41, 801-803. [CrossRef] [PubMed]

4. Gronenberg, W.; Tautz, J.; Hölldobler, B. Fast trap jaws and giant neurons in the ant Odontomachus. Science 1993, 5133, 561-563. [CrossRef] [PubMed]

5. Patek, S.N.; Baio, J.E.; Fisher, B.L.; Suarez, A.V. Multifunctionality and mechanical origins: Ballistic jaw propulsion in trap-jaw ants. Proc. Natl. Acad. Sci. USA 2006, 103, 12787-12792. [CrossRef] [PubMed]

6. Gronenberg, W.; Tautz, J.; Hoildobler, B. Fast Trap Jaws and Giant Neurons in the Ant Odontomachus. Science 1993, 262, 561-563. [CrossRef] [PubMed]

7. Rodriguez-Acosta, A.; Sánchez, E.E.; Navarrete, L.F. Intense allergic reaction in a patient stung by the black ant (Odontomachus bauri). Rev. Cuba. Med. Trop. 2006, 1, 77-80.

8. Fox, E.G.; Bueno, O.C.; Yabuki, A.T.; de Jesus, C.M.; Solis, D.R.; Rossi, M.L.; Nogueira Nde, L. General morphology and ultrastructure of the venom apparatus and convoluted gland of the fire ant, Solenopsis saevissima. J. Insect Sci. 2010, 10, 24. [CrossRef] [PubMed]

9. Billen, J.; Stroobants, Z.; Wenseleers, T.; Hashim, R.; Ito, F. Diversity and morphology of abdominal glands in workers of the ant genus Myopias (Formicidae, Ponerinae). Arthropod Struct. Dev. 2013, 42, 165-172. [CrossRef] [PubMed]

10. Wanandy, T.; Gueven, N.; Davies, N.W.; Brown, S.G.G.; Wiese, M.D. Pilosulins: A review of the structure and mode of action of venom peptides from an Australian ant Myrmecia pilosula. Toxicon 2015, 98, 54-61. [CrossRef] [PubMed]

11. Orivel, J.; Redeker, V.; le Caer, J.P.; Krier, F.; Revol-Junelles, A.M.; Longeon, A.; Chaffotte, A.; Dejean, A.; Rossier, J. Ponericins, new antibacterial and insecticidal peptides from the venom of the ant Pachycondyla goeldii. J. Biol. Chem. 2001, 276, 17823-17829. [CrossRef] [PubMed]

12. Morgan, E.D. Exocrine chemistry of the myrmicine ant Zacryptocerus pusillus (Hymenoptera: Formicidae). Arch. Insect Biochem. Physiol. 2006, 63, 11-14. [CrossRef] [PubMed]

13. Escoubas, P.; King, G.F. Venomics as a drug discovery platform. Expert Rev. Proteomics 2009, 6, $221-224$. [CrossRef] [PubMed]

14. Casewell, N.R.; Wüster, W.; Vonk, F.J.; Harrison, R.A.; Fry, B.G. Complex cocktails: The evolutionary novelty of venoms. Trends Ecol. Evol. 2013, 28, 219-229. [CrossRef] [PubMed]

15. Cologna, C.T.; dos Santos Cardoso, J.; Jourdan, E.; Degueldre, M.; Gregory, U.; Nicolas, G.; Trovatti Uetanabaro, A.P.; Costa Neto, E.M.; Thonart, P.; de Pauw, E.; et al. Peptidomic comparison and characterization of the major components of the venom of the giant ant Dinoponera quadriceps collected in four different areas of Brazil. J. Proteomics 2013, 94, 413-422. [CrossRef] [PubMed]

16. King, G.F.; Hardy, M.C. Spider-Venom Peptides: Structure, pharmacology, and potential for control of insect pests. Annu. Rev. Entomol. 2013, 58, 475-496. [CrossRef] [PubMed]

17. Smith, J.J.; Herzig, V.; King, G.F.; Alewood, P.F. The insecticidal potential of venom peptides. Cell. Mol. Life Sci. 2013, 70, 3665-3693. [CrossRef] [PubMed]

18. Vassilevski, A.A.; Kozlov, S.A.; Egorov, T.A.; Grishin, E.V. Purification and characterization of biologically active peptides from spider venoms. Methods Mol. Biol. 2010, 615, 87-100. [PubMed]

19. Bouzid, W.; Verdenaud, M.; Klopp, C.; Ducancel, F.; Noirot, C.; Vétillard, A. De Novo sequencing and transcriptome analysis for Tetramorium bicarinatum: A comprehensive venom gland transcriptome analysis from an ant species. BMC Genomics 2014, 15, 987. [CrossRef] [PubMed]

20. Aili, S.R.; Touchard, A.; Escoubas, P.; Padula, M.P.; Orivel, J.; Dejean, A.; Nicholson, G.M. Diversity of peptide toxins from stinging ant venoms. Toxicon 2014, 92, 166-178. [CrossRef] [PubMed]

21. Moreno, M.; Giralt, E. Three valuable peptides from bee and wasp venoms for therapeutic and biotechnological use: Melittin, apamin and mastoparan. Toxins 2015, 7, 1126-1150. [CrossRef] [PubMed]

22. Hoffman, D.R. Hymenoptera Venom Allergens. Clin. Rev. Allergy Immunol. 2006, 30, 109-128. [CrossRef] 
23. Vetter, I.; Davis, J.L.; Rash, L.D.; Anangi, R.; Mobli, M.; Alewood, P.F.; Lewis, R.J.; King, G.F. Venomics: A new paradigm for natural products-based drug discovery. Amino Acids 2010, 40, 15-28. [CrossRef] [PubMed]

24. Wiese, M.D.; Chataway, T.K.; Davies, N.W.; Milne, R.W.; Brown, S.G.; Gai, W.P.; Heddle, R.J. Proteomic analysis of Myrmecia pilosula (jack jumper) ant venom. Toxicon 2006, 47, 208-217. [CrossRef] [PubMed]

25. Gonzalez, D.; Zhao, Q.; McMahan, C.; Velasquez, D.; Haskins, W.E.; Sponsel, V.; Cassill, A.; Renthal, R. The major antennal chemosensory protein of red imported fire ant workers. Insect Mol. Biol. 2009, 18, 395-404. [CrossRef] [PubMed]

26. Whitworth, S.T.; Blum, M.S.; Travis, J. Proteolytic enzymes from larvae of the fire ant, Solenopsis invicta. Isolation and characterization of four serine endopeptidases. J. Biol. Chem. 1998, 273, 14430-14434. [CrossRef] [PubMed]

27. Qiu, Y.; Choo, Y.M.; Yoon, H.J.; Jia, J.; Cui, Z.; Wang, D.; Kim, D.H.; Sohn, H.D.; Jin, B.R. Fibrin(ogen)olytic activity of bumblebee venom serine protease. Toxicol. Appl. Pharmacol. 2011, 255, 207-213. [CrossRef] [PubMed]

28. Smeller, L. Protein denaturation on p-t axes-Thermodynamics and analysis. Subcell. Biochem. 2015, 72, 19-39. [PubMed]

29. Bouzid, W.; Klopp, C.; Verdenaud, M.; Ducancel, F.; Vétillard, A. Profiling the venom gland transcriptome of Tetramorium bicarinatum (Hymenoptera: Formicidae): The first transcriptome analysis of an ant species. Toxicon 2013, 70, 70-81. [CrossRef] [PubMed]

30. Zheng, Y.; Ye, F.P.; Wang, J.; Liao, G.Y.; Zhang, Y.; Fan, Q.S.; Lee, W.H. Purification, characterization and gene cloning of Da-36, a novel serine protease from Deinagkistrodon acutus venom. Toxicon 2013, 67, 1-11. [CrossRef] [PubMed]

31. Sah, H.; Kim, K.S. Improvement of Interfacial Protein Stability by CHAPS. Biotechnol. Lett. 2006, 28, 567-570. [CrossRef] [PubMed]

32. Saikia, D.; Majumdar, S.; Mukherjee, A.K. Mechanism of in vivo anticoagulant and haemolytic activity by a neutral phospholipase A(2) purified from Daboia russelii russelii venom: Correlation with clinical manifestations in Russell's Viper envenomed patients. Toxicon 2013, 76, 291-300. [CrossRef] [PubMed]

33. De Souza, B.M.; da Silva, A.V.; Resende, V.M.; Arcuri, H.A.; dos Santos Cabrera, M.P.; Ruggiero Neto, J.; Palma, M.S. Characterization of two novel polyfunctional mastoparan peptides from the venom of the social wasp Polybia paulista. Peptides 2009, 30, 1387-1395. [CrossRef] [PubMed]

34. Mendes, M.A.; de Souza, B.M.; Marques, M.R.; Palma, M.S. Structural and biological characterization of two novel peptides from the venom of the neotropical social wasp Agelaia pallipes pallipes. Toxicon 2004, 44, 67-74. [CrossRef] [PubMed]

35. Touchard, A.; Labriere, N.; Roux, O.; Petitclerc, F.; Orivel, J.; Escoubas, P.; Koh, J.M.S.; Nicholson, G.M.; Dejean, A. Venom toxicity and composition in three Pseudomyrmex ant species having different nesting modes. Toxicon 2014, 88, 67-76. [CrossRef] [PubMed]

36. Nget-Hong, T.; Gnanajothy, P. Comparative study of the enzymatic, hemorrhagic, procoagulant and anticoagulant activities of some animal venoms. Camp. Biochem. Physiol. 1992, 36, 299-302. [CrossRef]

37. Han, J.; You, D.; Xu, X.; Han, W.; Lu, Y.; Lai, R.; Meng, Q. An anticoagulant serine protease from the wasp venom of Vespa magnifica. Toxicon 2008, 51, 914-922. [CrossRef] [PubMed]

38. Costa Jde, O.; Fonseca, K.C.; Mamede, C.C.; Beletti, M.E.; Santos-Filho, N.A.; Soares, A.M.; Arantes, E.C.; Hirayama, S.N.; Selistre-de-Araujo, H.S.; Fonseca, F.; et al. Bhalternin: Functional and structural characterization of a new thrombin-like enzyme from Bothrops alternatus snake venom. Toxicon 2010, 55, 1365-1377. [CrossRef] [PubMed]

39. Gutierrez, J.M.; Rucavado, A.; Chaves, F.; Diaz, C.; Escalante, T. Experimental pathology of local tissue damage induced by Bothrops asper snake venom. Toxicon 2009, 54, 958-975. [CrossRef] [PubMed]

40. Xu, X.; Yang, H.; Yu, H.; Li, J.; Lai, R. The mastoparanogen from wasp. Peptides 2006, 27, 3053-3057. [CrossRef] [PubMed]

41. Bhattacharya, S.; Ghosh, P.; de, T.; Gomes, A.; Gomes, A.; Dungdung, S.R. In vivo and in vitro antileishmanial activity of Bungarus caeruleus snake venom through alteration of immunomodulatory activity. Exp. Parasitol. 2013, 135, 126-133. [CrossRef] [PubMed]

42. Bradford, M.M. A rapid and sensitive method for the quantitation of microgram quantities of protein utilizing the principle of protein-dye binding. Anal. Biochem. 1976, 72, 248-254. [CrossRef] 
43. Laemmli, U.K. Cleavage of structural proteins during the assembly of the head of bacteriophage T4. Nature 1970, 227, 680-685. [CrossRef] [PubMed]

44. Zanphorlin, L.M.; Cabral, H.; Arantes, E.; Assis, D.; Juliano, L.; Juliano, M.A.; Da-Silva, R.; Gomes, E.; Bonilla-Rodriguez, G.O. Purification and characterization of a new alkaline serine protease from the thermophilic fungus Myceliophthora sp. Process Biochem. 2011, 46, 2137-2143. [CrossRef]

45. Heussen, C.; Dowdle, E.B. Electrophoretic analysis of plasminogen activators in polyacrylamide gels containing sodium dodecyl sulfate and copolymerized substrates. Anal. Biochem. 1980, 102, 196-202. [CrossRef]

46. Edgar, W.; Prentice, C.R.M. The proteolytic action of ancrod on human fibrinogen and its polypeptide chains. Thromb. Res. 1973, 2, 85-95. [CrossRef]

47. Menezes, M.C.; Furtado, M.F.; Travaglia-Cardoso, S.R.; Camargo, A.C.M.; Serrano, S.M.T. Sex-based individual variation of snake venom proteome among eighteen Bothrops jararaca siblings. Toxicon 2006, 47, 304-312. [CrossRef] [PubMed]

48. Mosmann, T. Rapid colorimetric assay for cellular growth and survival: Application to proliferation and cytotoxicity assays. J. Immunol. Methods 1983, 65, 55-63. [CrossRef]

49. Denson, K.W.; Russell, F.E.; Almagro, D.; Bishop, R.C. Characterization of the coagulant activity of some snake venoms. Toxicon 1972, 10, 557-562. [CrossRef]

50. Gene, J.A.; Roy, A.; Rojas, G.; Gutierrez, J.M.; Cerdas, L. Comparative study on coagulant, defibrinating, fibrinolytic and fibrinogenolytic activities of Costa Rican crotaline snake venoms and their neutralization by a polyvalent antivenom. Toxicon 1989, 27, 841-848. [CrossRef]

51. Yagmur, G.; Ercal, B.D.; Mengeloglu, Z.; Sariguzel, F.M.; Berk, E.; Saglam, D. Is rapid antibacterial susceptibility testing medium reliable for routine laboratory practices? Pak. J. Med. Sci. 2015, 31, 351-354. [CrossRef] [PubMed]

52. De Oliveira, T.C.; Silva, D.A.; Rostkowska, C.; Bela, S.R.; Ferro, E.A.; Magalhaes, P.M.; Mineo, J.R. Toxoplasma gondii: Effects of Artemisia annua L. on susceptibility to infection in experimental models in vitro and in vivo. Exp. Parasitol. 2009, 122, 233-241. [CrossRef] [PubMed]

53. Jones-Brando, L.; D'Angelo, J.; Posner, G.H.; Yolken, R. In Vitro Inhibition of Toxoplasma gondii by Four New Derivatives of Artemisinin. Antimicrob. Agents Chemother. 2006, 50, 4206-4208. [CrossRef] [PubMed]

(C) 2015 by the authors; licensee MDPI, Basel, Switzerland. This article is an open access article distributed under the terms and conditions of the Creative Commons by Attribution (CC-BY) license (http://creativecommons.org/licenses/by/4.0/). 